\title{
Aplikasi Model Rasch dalam Mengukur Komitmen Dosen
}

\author{
Rina Anindita; Lukman Cahyadi \\ Magister Manajemen Fakultas Ekonomi dan Bisnis Universitas Esa Unggul \\ Jl. Arjuna Utara, Jakarta 15110, Indonesia \\ rina.anindita@esaunggul.ac.id
}

Article received: February 2020; revised: March 2020 ; accepted : July 2020

DOI : 10.17977/um025v4i32020p220

\begin{abstract}
Employee commitment and engagement is one of the keys to organizational success. Furthermore, in a higher education instituion, it is important to measure the commitment and engagement of lecturers in it in an effort to improve quality and performance. However, there is no specific measurement to measure the level of commitment and special attachment to lecturers. The purpose of this study is to find alternative instruments, measurements, and scales for surveys that can measure the level of lecturer commitment to the profession and their higher education appropriately. The study was conducted by survey method, of 136 lecturers in Jakarta and surrounding areas. Initial measurements used 13 item, which were then processed by RASCH modeling. The RASCH model analysis showed that there were 11 item measures that could be suggested for further research in measuring the commitment and attachment of lecturers, of which these 11 items were not biased towards age, educational background and lecturer status, but were biased towards the length of service. In addition to the items, the results of the study show that the measurement of the items can be done with a four-level Likert scale. The implication obtained from the results of this study is that these 11 measures can be used for research that measures the level of commitment and attachment of lecturers. The implication of this research is the measurement items for commitment and engagement of lecturers can be used in further research and analysis.
\end{abstract}

Keywords : Lecturer's Commitment, RASCH model, Higher Education

\begin{abstract}
Abstrak: Komitmen dan keterlibatan karyawan adalah salah satu kunci keberhasilan organisasi. Selanjutnya, dalam lembaga pendidikan tinggi, penting untuk mengukur komitmen dan keterlibatan dosen di dalamnya dalam upaya untuk meningkatkan kualitas dan kinerja. Namun, tidak ada pengukuran khusus untuk mengukur tingkat komitmen dan keterikatan khusus kepada dosen. Tujuan dari penelitian ini adalah untuk menemukan instrumen alternatif, pengukuran, dan skala untuk survei yang dapat mengukur tingkat komitmen dosen terhadap profesi dan pendidikan tinggi mereka secara tepat. Penelitian dilakukan dengan metode survei, dari 136 dosen di Jakarta dan sekitarnya. Pengukuran awal menggunakan 13 item, yang kemudian diproses oleh pemodelan RASCH. Analisis model RASCH menunjukkan bahwa ada 11 item ukuran yang dapat disarankan untuk penelitian lebih lanjut dalam mengukur komitmen dan keterikatan dosen, di mana 11 item ini tidak bias terhadap usia, latar belakang pendidikan dan status dosen, tetapi bias terhadap panjangnya. layanan. Selain item, hasil penelitian menunjukkan bahwa pengukuran item dapat dilakukan dengan skala Likert empat tingkat. Implikasi yang diperoleh dari hasil penelitian ini adalah bahwa 11 langkah ini dapat digunakan untuk penelitian yang mengukur tingkat komitmen dan keterikatan dosen. Implikasi dari penelitian ini adalah item pengukuran untuk komitmen dan keterlibatan dosen dapat digunakan dalam penelitian dan analisis lebih lanjut.
\end{abstract}

Kata kunci: Komitmen Dosen, model RASCH, Pendidikan Tinggi 
Praktisi Sumber Daya Manusia (SDM) memandang karyawan sebagai suatu aset terpenting dalam suatu organisasi, sehingga dianggap sangat berperan dalam mendukung tercapainya tujuan organisasi. Employee engagement dan komitmen organisasional merupakan variabel yang berperan dalam peningkatan kinerja karyawan dalam mencapai tujuannya (Markos dan Sridevi, 2010; Jaros, 2007; Meyer dan Allen,1997; Metha dan Metha, 2013). Dalam hal ini dengan adanya employee engagement, karyawan akan memiliki rasa keterikatan dengan perusahaan sehingga individu terdorong dan antusias dalam melaksanakan tugasnya. Konsekuensi dari employee engagement yang kuat yaitu komitmen organisasional (Saks, 2006). Besarnya pengaruh employee engagement dan komitmen organisasional terhadap performansi perusahaan membuat peneliti tertarik untuk membahas lebih jauh mengenai hal tersebut, terutama dalam mendukung performansi karyawan dalam sebuah perusahaan yang baru berkembang dan memiliki skala internasional. Perusahaan yang masih dalam tahap perkembangan sangat membutuhkan karakteristik karyawan yang memiliki employee engagement maupun komitmen organisasional untuk terus beradaptasi dengan segala perubahan dan inovasi baru untuk melaksanakan strategi perusahaan (Zulkarnain dan Hadiyani, 2014).

Ortiz dan Lau (2011), menunjukkan bagaimana hubungan employee engagement dengan dimensi yang ada pada komitmen organisasional. Anindita dan Seda (2018) dalam penelitiannya menunjukkan bahwa komitmen organisasional dapat terbentuk dengan adanya goal setting, employee engagement dan rasa optimis pada perusahaan. Namun hal tersebut dapat terbentuk jika ketiganya dapat di implementasikan dengan baik, yaitu melakukan goal setting antara karyawan dan manajemen sehingga karyawan menjadi ikut terlibat dalam setiap pekerjaan yang dilakukan. Dengan demikian kerja sama yang terjadi menimbulkan adanya keterikatan dan rasa optimis karyawan dalam bekerja, hal inilah yang mendukung terjadinya peningkatan komitmen karyawan pada organisasinya.

Karyawan yang bekerja pada organisasi swasta atau perusahaan swasta lebih memiliki employee engagement dan komitmen organisasional yang lebih tinggi dari pada karyawan yang bekerja pada organisasi publik atau perusahaan milik negara. Shoko dan Zinyemba (2014) dalam penelitiannya memperlihatkan bahwa employee engagement pada karyawan yang berada pada institut perguruan tinggi milik negara tergolong lemah, namun penelitian ini juga memperlihatkan adanya hubungan yang positif antara employee engagement dan komitmen organisasional pada karyawan. Disamping itu ditemukan bahwa karyawan yang didorong dengan adanya pengakuan dan pujian, training dan memiliki kesempatan berkembang, rekan kerja, adanya prestasi, kejelasan dalam pekerjaan, presepsi karyawan mengenai pentingnya pekerjaan, kesempatan untuk berprestasi, dukungan, pengawasan, dan memiliki rekan kerja yang baik sangat mendorong terbentuknya employee engagement yang kuat pada karyawan. Khalid dan Khalid (2015) mengatakan bahwa employee engagement memiliki pengaruh yang lebih signifikan terhadap komitmen organisasional daripada career satisfaction.

Walaupun pada penelitian dan teori terdahulu telah banyak membahas bagaimana ukuran dan pentingnya engagement dan komitmen karyawan, namun belum ada yang secara spesifik mengukur komitmen dosen pada perguruan tinggi swasta. Sehingga tujuan yang ingin dicapai dalam penelitian ini adalah memberikan rekomendasi ukuran engagement dan komitmen apabila subyek yang diteliti adalah dosen pada perguruan tinggi swasta.

Allen dan Meyer (1991) merumuskan komitmen dalam sebuah organisasi sebagai suatu bentuk psikologis yang merupakan hubungan antara karyawan dengan organisasinya, dan memiliki dampak yang kuat apakah karyawan akan bertahan pada organisasi tersebut atau tidak. Hal ini juga didukung oleh Meyer dan Herscovitch (2001) yang mengatakan bahwa komitmen merupakan kekuatan individu dalam melakukan sesuatu yang sesuai dengan tujuan dari perusahaan. Mowday, et al. (1997) mendifinisikan Organizational Commitment (OC) sebagai suatu konsep multidimensional yang mampu membuat karyawan melakukan sesuatu atas nama perusahaan, dengan percaya dan menerima nilai serta tujuan dari sebuah organisasi.

Komitmen organisasional ialah tingkatan dimana seseorang memposisikan dirinya pada organisasi dan memiliki kemauan untuk melanjutkan upaya pencapaian tujuan organisasinya (Noe, 2000). Komitmen organisasional juga didefinisikan sebagai keadaan seorang karyawan yang memihak 
dan mendukung dalam suatu organisasi dengan tujuan-tujuannya, serta berniat untuk memelihara keanggotaannya dalam organisasi tersebut (Robinson, et al., 2006). Sehingga dapat disimpulkan bahwa komitmen organisasional merupakan hubungan psikologis antara karyawan dan organisasinya dengan menerima dan menjalankan tujuan-tujuan yang telah ditetapkan, serta memiliki dampak yang kuat untuk tetap bertahan dalam organisasi tersebut.

Tsai dan Huang (2008) menyatakan komitmen organisasional adalah hubungan antara perasaan individu dengan pekerjaannya dan juga organisasinya. Komitmen organisasional umumnya didefinisikan sebagai kepedulian karyawan di asosiasi dengan organisasinya menurut (Danish et al., 2015). Sedangkan menurut Weihui dan Zhao (2011) komitmen organisasional adalah perbandingan kekuatan empati individu dengan asosiasi dalam organisasi tertentu (Danish et al., 2015). Menurut Cichy dan Kim (2009) komitmen organisasional disepakati sebagai niat individu atau keinginan untuk tinggal didalam organisasi saat ini dan perilaku individu ke organisasi dan ditampilkan dalam kekuatan hubungan seseorang dan empati dengan organisasi (Danish et al., 2015).

Meyer dan Allen (1997) mendefinisikan komitmen organisasional sebagai keadaan psikologis yang ikut merasakan bagaimana seorang individu memiliki keterlibatan didalam organisasi mereka dan keinginan untuk terus tetap didalam organisasi. (1) Komitmen afektif didefinisikan sebagai keinginan karyawan untuk secara emosional melekat pada identifikasi dengan dan keterlibatan dalam organisasi. Individu karyawan yang telah merasakan komitmen afektif yang lebih tinggi akan lebih mungkin dan bersedia untuk tetap dengan masing-masing organisasi karena mereka ingin. Jika seorang karyawan tidak mempunyai rasa memiliki terhadap organisasi, maka mereka cenderung memiliki sedikit keinginan untuk terikat secara emosional dalam organisasi; (2) Komitmen berkelanjutan didefinisikan sebagai kesadaran atau pengakuan manfaat karyawan untuk tetap dalam organisasi versus biaya yang dikeluarkan ketika meninggalkan organisasi. Jika individu merasakan biaya meninggalkan jauh lebih besar dari pada tetap dalam organisasi, maka karyawan tertentu akan berencana untuk tinggal daripada meninggalkan organisasi itu; (3) Komitmen normatif didefinisikan sebagai konsekuensi dari perasaan karyawan dengan kewajiban untuk berada di organisasi berdasarkan norma pribadi dan nilai-nilai organisasi. Keputusan cuti atau tinggal sebenarnya didasarkan pada keyakinan individu karyawan dari hak dan hal moral untuk dilakukan. Jika seorang karyawan merasa bahwa ia harus setia kepada organisasi masing-masing, maka ia harus tetap sebagai anggota dari organisasi tersebut. Biasanya, karyawan akan melihat komitmen afektif yang lebih tinggi dari komitmen normatif, namun, rendah dari komitmen berkelanjutan.

Robbins (2001) dalam Bui dan Baruch (2010) mengatakan bahwa komitmen organisasi adalah sampai tingkat mana seorang karyawan memihak organisasi dan tujuannnya, berniat memelihara keanggotaan dalam organisasi. Komitmen organisasi yang tinggi berarti adalah keberpihakan yang tinggi pada organisasi yang tinggi pula. Menurut Konsep dasar Komitmen Organisasi berangkat dari Greenberg dan baron (1993) serta teori dari Mowday, Porter dan Dubin (1974) seperti yang dikutip oleh Yen (2011) adalah sikap yang mencerminkan posisi individu dalam perusahaan, merasa dirinya identik dan terlibat dalam organisasi dan pekerjaan sebagai perorangan dan tidak memiliki keingingan untuk meninggalkan orgnaisasi.

Komitmen organisasi mengarah kepada keterkaitan psikologis karyawan dengan tempat kerjanya, dimana objek dari komitmen adalah organisasi, namun dapat juga kepada orang dan gagasan, praktek dan pekerjaan (Meyer \& Allen, 1991; Meyer, Allen \& Smith, 1993) dalam Lie, et al (2011). Atau dapat dikatakan sebagai perilaku dalam bekerja, dimana tingkat komitmen menunjukkan seberapa berkomitmen seorang karyawan terhadap organisasinya (Steer dalam Lie, 2011) dan perilaku atau kecenderungan hubungan karyawan dengan organisasinya ditambahkan dengan keyakinan yang kuat terhadap tujuan dan nilai-nilai organisasi, menggunakan segala daya dan uaya untuk mewujudkan pada organisasi serta keyakinan yang kuat untuk tetap berada pada organisasi. (Mowday, proter dan Steers dalam Lie 2011). Ditambahkan juga terdapat tiga komponen dari komitmen organisasi, yaitu : komponen 
afektif, yang mengacu kecenderungan emosional karyawan, komponen berkelanjutan, yaitu mengacu pada biaya yang diperoleh selama hidup dalam organisasi dan komponen normative yang mengacu kepada kewajiban karyawan terhadap organisasi.

\section{METODE}

Penelitian dilaksanakan pada perguruan tinggi swasta yang tersebar di Jakarta, Depok, Tangerang, dan Bekasi, Indonesia, mulai Juli sampai Oktober 2018. Pemodelan Rasch digunakan untuk analisis data kuesioner. Disain penelitian adalah kuantitatif dengan metode survei. Pendekatan waktu yang digunakan adalah one shot crossectional study dengan subyek adalah dosen tetap yang sudah bekerja minimal 1 tahun pada perguruan tinggi swasta pangkalan saat ini. Jumlah yang ditetapkan adalah sebanyak 200 dosen, namun kuesioner yang kembali sebanyak 136 kuesioner.

Penelitian mengukur 1 variabel, yaitu komitman dan keterikatan. Aspek karakterstik responden yang diukur dalam penelitian ini adalah jenis kelamin, lama bekerja, jenjang pendidikan terakhir, usia dan status dosen tersebut. Jenis skala pengukuran yang digunakan adalah skala peringkat LIKERT, dengan empat pilihan pertanyaan.

Ukuran yang digunakan untuk mengukur engagement dosen terdapat 13 ukuran, yang diambil dari beberapa sumber pada kajian literatur, yaitu: bersungguh-sungguh menjalani profesi; profesi yang menyita waktu; keterlibatan dengan profesi dosen,; merasa berarti sebagai dosen; kebanggaan sebagai dosen; keterlibatan dengan organisasi; menghabiskan karir pada organisasi; melibatkan dalam penyelesaian masalah organisasi; ikatan emosional pada organisasi; kebutuhan untuk bertahan pada organisasi; tidak meninggalkan organisasi; kerugian meninggalkan organisasi; dan perasaan bersalah meninggalkan organisasi.

Data mentah menggunakan hasil pengukuran dari kuesioner yang berbentuk skala ordinal, kemudian ditransformasi dalam bentuk logit, menjadi skala interval melalui perangkat lunak statistik, Winsteps. Jenis analisis untuk menilai persepsi dosen terhadap tingkat engagement menggunakan pemodelan Rasch. Dimana pemodelan Rasch merupakan alat analisis yang dapat menguji validtas dan reliabilitas secara detail dari instrumen riset, dengan menguji kesesuaian person dan item dengan simultan.

Pengukuran dengan Rasch model membutuhkan data yang cukup banyak minimal 250 responden agar hasil yang didapat stabil, penelitian ini hanya menggunakan data 136 responden. Keterbatasan yang kedua adalah, responden yang tidak misfit masih diikutsertakan pada analisis ini. Dan keterbatasan yang ketiga, cakupan survey penyebaran kuesioner terbatas pada wilayah Jakarta dan Tangerang, Indonesia kepada 14 Perguruan Tinggi Swasta.

\section{HASIL DAN PEMBAHASAN}

Percobaan pertama dengan jumlah 136 person responden dengan 13 item engagement

Tahap 1 : Summary Statistics

Tahap summary statistic, memastikan adanya interaksi yang baik antara respon responden dengan item yang diukur. 


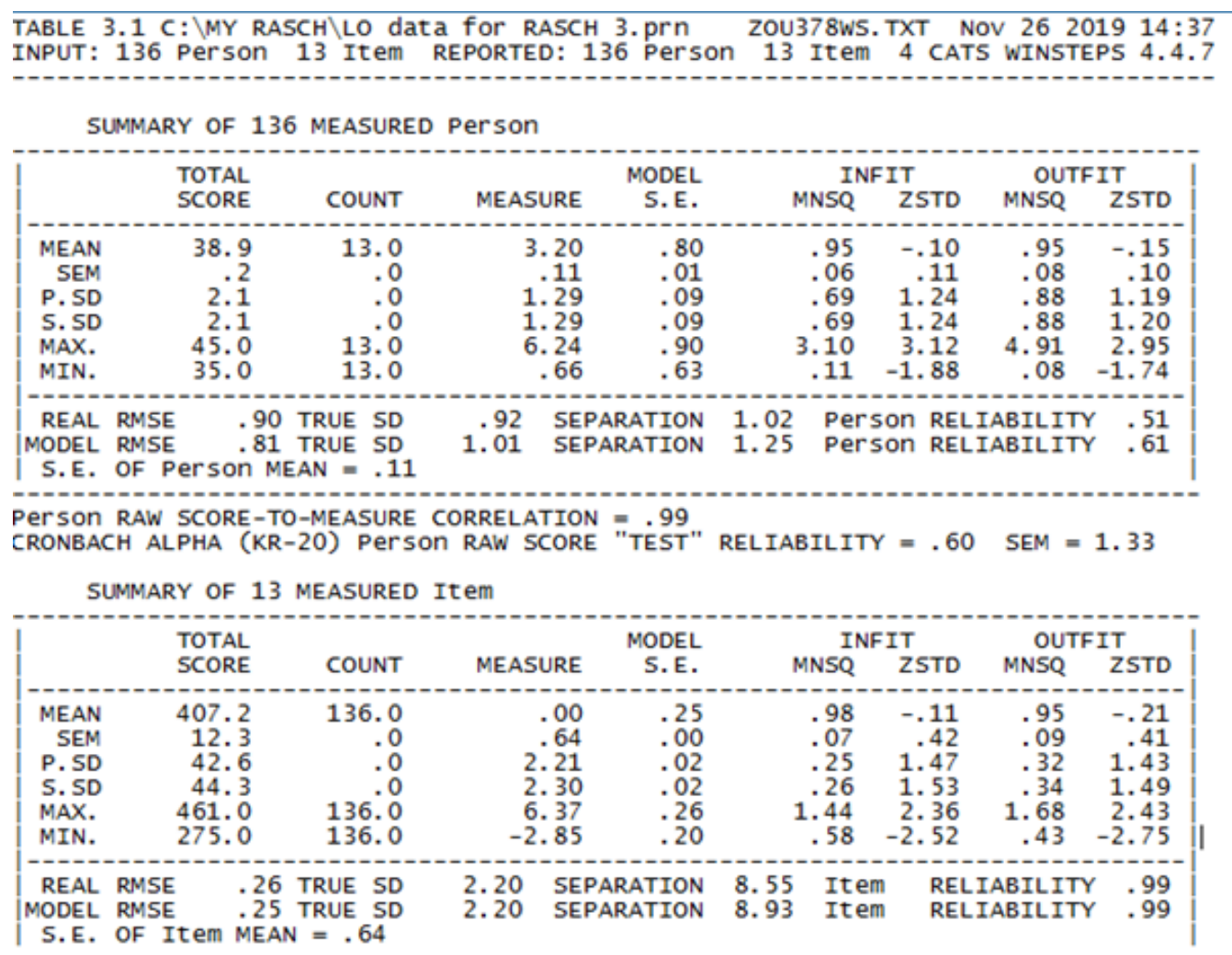

Gambar 1 Summary Statistic

Pada Gambar 1, memberikan info kualitas responden secara keseluruhan, dimana info ini juga menunjukkan kualitas instrumen digunakan dengan melihat interaksi antara person (responden) dengan item.

Hal yang dilihat dalam Gambar 1

1. Nilai Person Measure $=+3.2$ logit, ini menunjukkan, rata-rata nilai responden dalam instrumen engagement dosen. Nilai rata-rata yang lebih tinggi dari logit 0.0 menunjukkan kecenderungan responden yang lebih banyak menjawab setuju di berbagai item.

2. Nilai cronbach alpha, terlihat nilai nya $0.6 \mathrm{n}$ artinya kurang baik.

3. Person reliability 0,51 dan item reliability 0.99 , arinya dapat disimpulkan bahwa konsistensi jawaban responden lemah, namun kualitas item dalam insturmen bagus

4. Nilai INFIT MNSQ dan OUTFIT MNSQ pada person, nilainya 0,95 dan 0,95 , dimana nilai idealnya adalah 1 . Artinya baik, karena nilai mendekati 1 . Sedangkan nilai INFIT ZSTD dan OUTFIT ZSTD untuk person adalah -0.1 dan -0.15 , mendekati 0 , artinya baik. Hal yang sama juga terlihat pada tabel item.

5. Untuk mengelompokkan person dan item dilihat pada nilai separation. Nilai separation pada person adalah 1.09 dengan rumus $[(4 \times 1.09)+1] / 3=1.79$ artinya terdapat dua kelompok responden dalam penelitian ini.

\section{Tahap 2 : Item Measure}

Tahap ini digunakan untuk mengukur atau memberikan informasi tentang item yang paling sukar dan paling mudah disetujui oleh responden. 


\begin{tabular}{|c|c|c|c|c|c|c|c|c|c|c|c|c|c|}
\hline \multicolumn{14}{|c|}{ 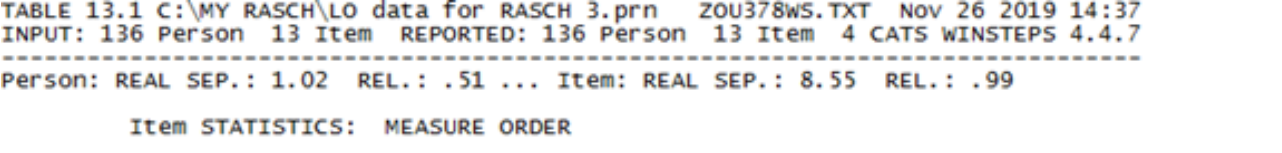 } \\
\hline $\begin{array}{l}\text { ENTRY } \\
\text { NUMBER }\end{array}$ & $\begin{array}{l}\text { TOTAL } \\
\text { SCORE }\end{array}$ & $\begin{array}{l}\text { TOTAL } \\
\text { COUNT }\end{array}$ & MEASURE & $\begin{array}{l}\text { MODEL } \\
\text { S.E. }\end{array}$ & MNSQ & $\begin{array}{l}\text { FIT } \\
\text { ZSTD }\end{array}$ & \begin{tabular}{|} 
OUT \\
MNSQ
\end{tabular} & $\begin{array}{l}\text { FFIT } \\
\text { ZSTD }\end{array}$ & $\begin{array}{l}\text { PTMEAS } \\
\text { |CORR. }\end{array}$ & $\begin{array}{r}\text { SUR-AL. } \\
\text { EXP. | }\end{array}$ & $\begin{array}{r}\text { EXACT } \\
\text { OBS\% }\end{array}$ & $\begin{array}{r}\text { MATCH } \\
\text { EXP\% }\end{array}$ & Item \\
\hline $\begin{array}{r}2 \\
11 \\
12 \\
8 \\
10 \\
7 \\
4 \\
13 \\
3 \\
5 \\
6 \\
9 \\
1\end{array}$ & $\begin{array}{l}275 \\
391 \\
391 \\
397 \\
398 \\
420 \\
423 \\
424 \\
428 \\
428 \\
428 \\
430 \\
461\end{array}$ & $\begin{array}{l}136 \\
136 \\
136 \\
136 \\
136 \\
136 \\
136 \\
136 \\
136 \\
136 \\
136 \\
136 \\
136\end{array}$ & $\begin{array}{r}6.37 \\
1.35 \\
1.35 \\
.96 \\
.89 \\
-.77 \\
-.98 \\
-1.04 \\
-1.29 \\
-1.29 \\
-1.29 \\
-1.41 \\
-2.85\end{array}$ & $\begin{array}{l}.22 \\
.25 \\
.25 \\
.26 \\
.26 \\
.26 \\
.26 \\
.25 \\
.24 \\
.24 \\
.24 \\
.24 \\
.20\end{array}$ & $\begin{array}{r}1.37 \\
1.44 \\
.76 \\
.58 \\
.86 \\
1.25 \\
.84 \\
.98 \\
1.05 \\
.86 \\
.76 \\
.86 \\
1.15\end{array}$ & $\begin{array}{r}2.07 \\
2.36 \\
-1.53 \\
-2.52 \\
-.71 \\
1.25 \\
-.89 \\
-.03 \\
.37 \\
-.88 \\
-1.60 \\
-.92 \\
1.60\end{array}$ & $\begin{array}{r}1.29 \\
1.68 \\
.68 \\
.43 \\
.85 \\
1.16 \\
.77 \\
.94 \\
1.14 \\
.72 \\
.62 \\
.84 \\
1.23\end{array}$ & $\begin{array}{r}1.45 \\
2.43 \\
-1.42 \\
-2.75 \\
-.50 \\
.66 \\
-.93 \\
-.16 \\
.66 \\
-1.22 \\
-1.82 \\
-.64 \\
1.55\end{array}$ & $\begin{array}{l}.11 \\
.54 \\
.46 \\
.36 \\
.41 \\
.56 \\
.27 \\
.54 \\
.16 \\
.47 \\
.44 \\
.62 \\
.36\end{array}$ & $\begin{array}{l}.44 \\
.39 \\
.39 \\
.37 \\
.37 \\
.38 \\
.40 \\
.40 \\
.42 \\
.42 \\
.42 \\
.42 \\
.49\end{array}$ & $\begin{array}{l}80.1 \\
77.2 \\
87.5 \\
91.9 \\
88.2 \\
82.4 \\
88.2 \\
86.0 \\
84.6 \\
86.0 \\
87.5 \\
84.6 \\
67.6\end{array}$ & $\begin{array}{l}81.8 \\
84.5 \\
84.5 \\
86.8 \\
87.2 \\
86.9 \\
86.0 \\
85.7 \\
84.2 \\
84.2 \\
84.2 \\
83.4 \\
72.9\end{array}$ & $\begin{array}{l}\text { E2 } \\
\text { E11 } \\
\text { E12 } \\
\text { E8 } \\
\text { E10 } \\
\text { E7 } \\
\text { E4 } \\
\text { E13 } \\
\text { E3 } \\
\text { E5 } \\
\text { E6 } \\
\text { E9 } \\
\text { E1 }\end{array}$ \\
\hline $\begin{array}{l}\text { MEAN } \\
\text { P.SD }\end{array}$ & $\begin{array}{r}407.2 \\
42.6\end{array}$ & $\begin{array}{r}136.0 \\
.0\end{array}$ & $\begin{array}{r}.00 \\
2.21\end{array}$ & $\begin{array}{l}.25 \\
.02\end{array}$ & $\begin{array}{l}.98 \\
.25\end{array}$ & -.15 & $\begin{array}{l}.95 \\
.32\end{array}$ & \begin{tabular}{r|}
-.2 \\
1.4
\end{tabular} & & & $\begin{array}{r}84.0 \\
6.0\end{array}$ & $\begin{array}{r}84.0 \\
3.5 \mid\end{array}$ & \\
\hline
\end{tabular}

Gambar 2 Reliabilitas Item

Output item measure menunjukkan urutan item yang sukar untuk disetujui oleh responden sampai item yang mudah disetujui oleh responden. Dalam output di atas, item no. 2 adalah item yang paling sukar disetujui oleh responden sedangkan item no. 1 adalah item yang paling mudah disetujui oleh responden.

\section{Tahap 3 : Item Fit Order}

Tahap ini berguna untuk mengukur atau memberikan informasi terkait item yang misft diurutkan dari yang paling tidak sesuai

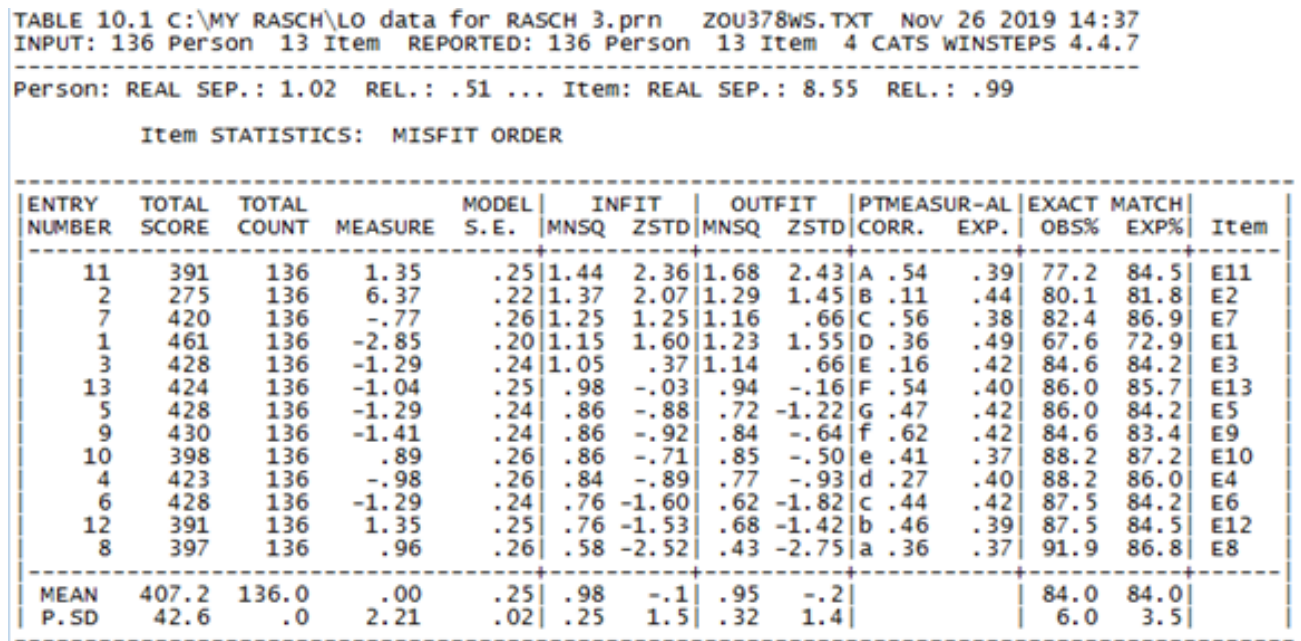

Gambar 3 Hasil Nilai Fit Item Komitmen Dosen

1. Untuk memeriksa item yang fit dan misfit bisa digunakan nilai INFIT MNSQ dari setiap item; nilai rata-rata dan deviasi standar yang dijumlahkan kemudian dibandingkan. Pada tabel di atas, nilai mean atau rata-rata dari logit adalah 0.98 , dengan nilai SD adalah 0.25 , jika dijumlahkan nilai $0.98+$ $0.25=1.23$ maka terlihat ada tiga item yang besarnya di atas 1,23 yaitu item $11(1.44), 2$ (1.37), dan 7 (1.25). 
2. Untuk memastikan dapat dengan melihat nilai OUTFIT MNSQ apakah terlaetak antara $0.5<$ MNSQ $<1.5$, dengan melihat kepada kriteria ini,maka item no. 11 (1.68) dan item no. 8 (0.43) tidak masuk ke dalam kriteria.

3. Cara ketiga adalah dengan melihat nilai OUTFIT ZSTD, nilai nya harus di rentang $-2.0<$ ZSTD $<2.0$; kembali dengan melihat standar ini, item no. 11 (2.43) dan item no. 8 (-2.75) merupakan item yang diperkirakan misfit.

\section{Tahap 4 ; Unidimensionalitas}

Tahap ini penting dilakukan karena memastikan apakah item instrumen yang dikembangkan, mampu mengukur apa yang akan diukur, artinya ingin memastikan apakah ke - 13 item ini benar mengukur engagement dosen atau tidak. Dasar yang digunakan juga menggunakan Prinncipal Component Analalysis dari residual.

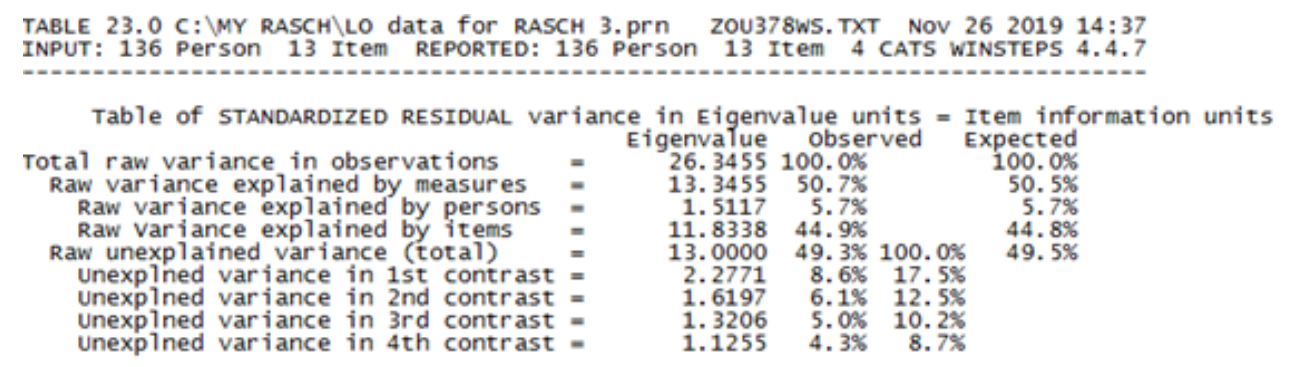

Gambar 4 Nilai Unidimensionalitas Item Komitmen Dosen

Dari Gambar 4 terlihat angka hasil penguukuran dari raw variance data adalah sebesar $50.7 \%$. nilai raw variance di atas $40 \%$ menunjukkan bahwa unidimensionalitas telah terpenuhi. Indikasi lain yang menunjukkan seluruh item adalan unidimensi adalah varians yang tidak dapat dijelaskan tidak ada yang mencapai $10 \%$, dalam tabel di atas nilai tertingginya $8.6 \%$, dibawah $10 \%$.

Tahap 5 : Skala Peringkat

Setelah memastikan bahwa seluruh item ada dalam satu kelompok (unidimensi), maka pengujian selanjutnya adalah memverifikasi, apakah peringkat yang digunakan untuk mengukur engagement dosen membingungkan atau tidak.

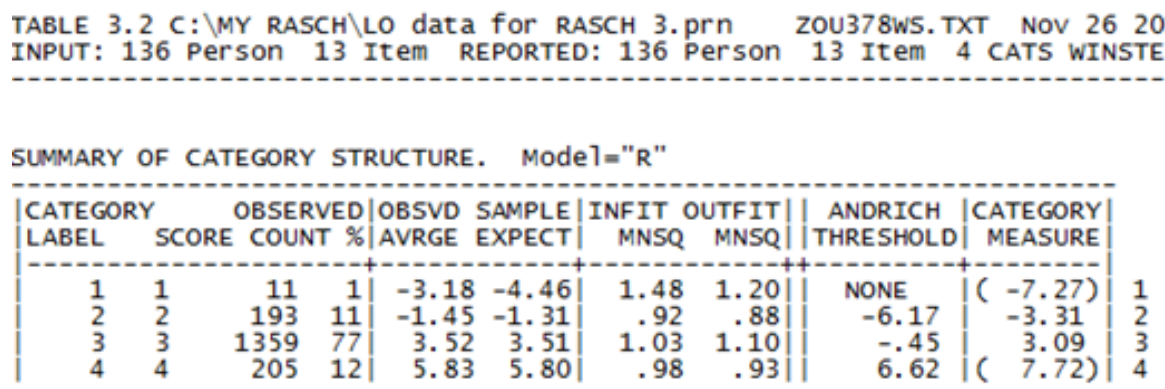

Gambar 5 Penentuan Skala Peringkat yang tepat untuk Komitmen Dosen

Pada Gambar 5 terlihat bahwa rata-rata observasi dimulai dari logit -3.18 untuk pilihan skor 1, sangat tidak setuju, dan terus meningkat sampai logit 5.38 untuk sangat setuju. Terlihat bahwa pada semua pilihat $1,2,3$, dan 4 , tidak terjadi turun naik artinya pola nya terus meningkat dari sangat tidak setuju sampai sangat setuju. Ukuran lain untuk memastikan skala peringkat yang tepat adalah Andrich 
Treshold, dimana terlihat bahwa nilai AT mulai dari none kemudian negatif dan mengarah secara berurutan sampai opsi sangat setuju. Oleh karena itu, skala empat peringkat sangat tidak setuju sampai sangat setuju disarankan untuk pengukuran engagement dosen.

\section{Tahap 6 : Perbaikan Item}

Perbaikan item perlu dilakukan oleh peneliti, karena nilai Cronbach Alpha pada angka 0.6, menunjukkan nilai yang kurang baik. Hal ini juga menunjukkan bahwa responden tidak konsisten dalam menjawab item. Adapun item yang membuat responden tidak konsisten dalam menjawab adalah item no. 11 dan item no. 8. Keputusan untuk menghilangkan 2 item ini berdasarkan hasil pada tahap ke-3 di atas.

Setelah melakukan perbaikan item, menggunakan responden yang sama, ternyata hal yang tidak terduga adalah nilai Cronbach Alpha turun menjadi 0.53. sehingga dilakukan pengecekan ulang tidak kepada item tetapi kepada responden. Maka pada tahap ke 7 menggunakan Person Fit, namun menggunakan data yang sama dengan data yang digunakan pada tahal 1 sampai 6 .

\section{Tahap 7 : Person Fit}

Tahap ini pada dasarnya sama dengan pemeriksaan item. Nilai rata-rata dari INFIT MNSQ adalah 0.95 dengan nilai SD adalah 0.69 , sehingga didapat penjumlahannya adalah 1.64. dengan melihat batas nilai tersebut pada INFIT MNSQ, terlihat da 15 responden yang misfit, yaitu responden no. 6, 51. 15 . 22. $65,70,8,115.47,77,85,66,124.53,29$ dan 2.

Sedangkan dengan melihat nilai OUFIT MNSQ yang layaknya berada pada $0.5<$ MNSQ $<1.5$, maka responden yang misfit adalah lebih dari 20 responden, karena ukuran ini menunjukkan banyak person yang misfit, maka alternatif digunakan OUTFIT ZSTD, yang standarnya -2, ZSTD $<2.0$. dengan ukuran OUTFIT ZSTD, responden atau person yang misfit, hanya responden no 6, 51, 15, 65 dan 8 .

Kelima responden ini, setelah dilakukan pengecekan di scalogram ternyata memang menunjukkan jawaban yang cenderung berbeda dengan teman sekelompoknya.

Tahap 8: Menentukan Faktor Demografi yang Menyebabkan Instrumen Menjadi Bias

8a. Faktor Bias : Jenis Kelamin

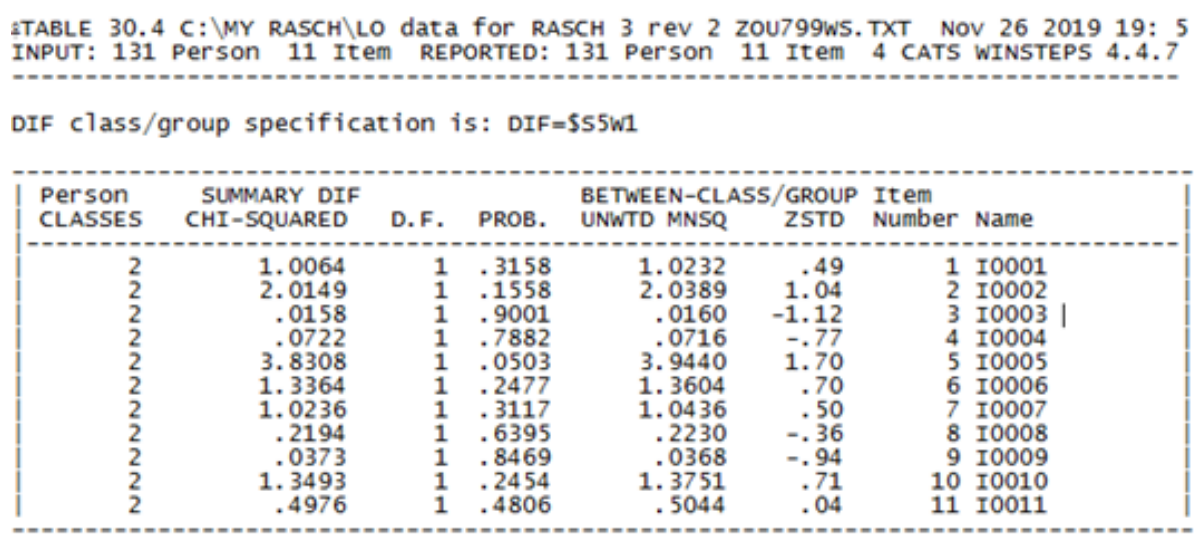

Gambar 6 Faktor Bias Jenis Kelamin

Tidak ada item yang bias terhadap jenis kelamin. Artinya, apakah dosen wanita ataupun pria, seluruh item dijawab dengan sama, artinya tidak berbeda tingkat komitmen dan engagement dosen lakilaki dengan dosen wanita. 
8b. Faktor Bias ; Tingkat Pendidikan

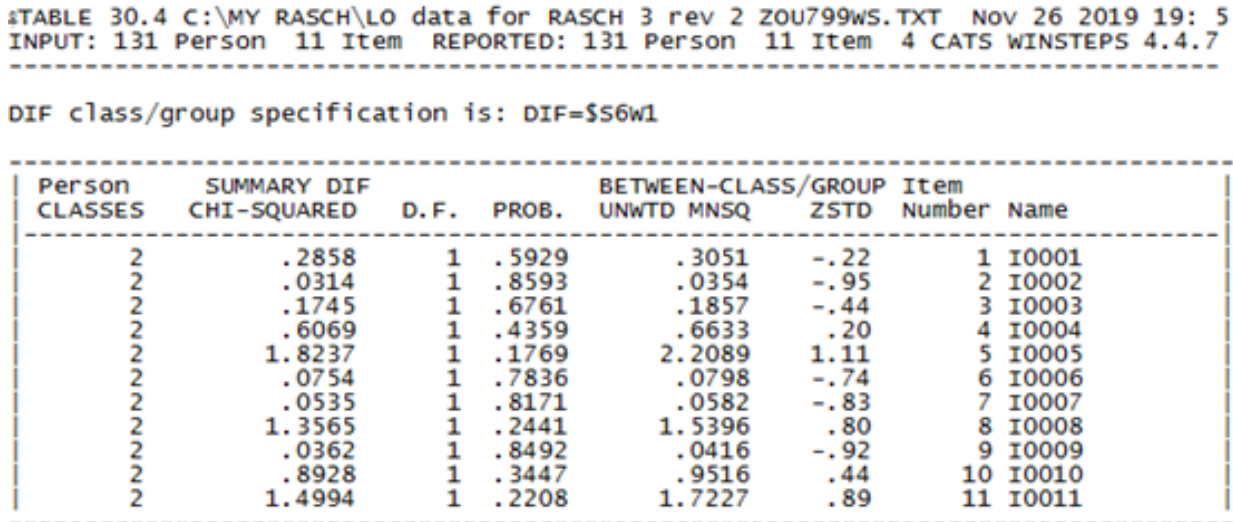

Gambar 7 Faktor Bias Tingkat Pendidikan

Tidak ada item yang bias dengan pendidikan terakhir dosen.

8c. Faktor Bias ; Status Dosen

\begin{tabular}{|c|c|c|c|c|c|c|c|c|}
\hline \multicolumn{9}{|c|}{ DIF class/group specification is: DIF=\$S7W1 } \\
\hline $\begin{array}{l}\text { Person } \\
\text { CLASSES }\end{array}$ & $\begin{array}{l}\text { SUMMARY DIF } \\
\text { CHI-SQUARED }\end{array}$ & D. F. & PROB. & $\begin{array}{l}\text { BETWEEN-CLA } \\
\text { UNWTD MNSQ }\end{array}$ & $\begin{array}{l}\text { ASS/GROUP } \\
\text { ZSTD }\end{array}$ & $\begin{array}{l}\text { Item } \\
\text { Number }\end{array}$ & Name & \\
\hline $\begin{array}{l}2 \\
2 \\
2 \\
2 \\
2 \\
2 \\
2 \\
2 \\
2 \\
2 \\
2\end{array}$ & $\begin{array}{r}2.0250 \\
1.2533 \\
2.0983 \\
1.2911 \\
1.1252 \\
.3843 \\
3.7616 \\
.7741 \\
.6071 \\
.2214 \\
3.8455\end{array}$ & $\begin{array}{l}1 \\
1 \\
1 \\
1 \\
1 \\
1 \\
1 \\
1 \\
1 \\
1 \\
1 \\
1\end{array}$ & $\begin{array}{l}.1547 \\
.2629 \\
.1475 \\
.2558 \\
.2888 \\
.5353 \\
.0524 \\
.3789 \\
.4359 \\
.6380 \\
.0499\end{array}$ & $\begin{array}{r}2.8885 \\
1.5915 \\
3.0237 \\
1.6644 \\
1.3793 \\
.4313 \\
6.9689 \\
.9122 \\
.6159 \\
.2299 \\
11.2888\end{array}$ & $\begin{array}{r}1.37 \\
.83 \\
1.42 \\
.86 \\
.71 \\
-.05 \\
2.40 \\
.41 \\
.15 \\
-.35 \\
3.11\end{array}$ & $\begin{array}{r}1 \\
2 \\
3 \\
4 \\
5 \\
6 \\
7 \\
8 \\
9 \\
10 \\
11\end{array}$ & $\begin{array}{l}\text { I0001 } \\
\text { I0002 } \\
10003 \\
10004 \\
10005 \\
10006 \\
10007 \\
10008 \\
10009 \\
10010 \\
10011\end{array}$ & \\
\hline
\end{tabular}

Gambar 8 Faktor Bias Status Dosen

Tidak ada item yang bias terhadap status dosen PNS atau pun yayasan.

8d. Faktor Bias : Masa Kerja

DIF class/group specification is: DIF $=\$ 58 W 1$

\begin{tabular}{|c|c|c|c|c|c|c|c|}
\hline $\begin{array}{l}\text { Person } \\
\text { CLASSES }\end{array}$ & $\begin{array}{l}\text { SUMMARY DIF } \\
\text { CHI-SQUARED }\end{array}$ & D. F. & PROB. & $\begin{array}{l}\text { BETWEEN-CLA } \\
\text { UNWTD MNSQ }\end{array}$ & $\begin{array}{l}\text { /GROUP } \\
\text { ZSTD }\end{array}$ & $\begin{array}{l}\text { Item } \\
\text { Number }\end{array}$ & Name \\
\hline $\begin{array}{l}2 \\
2 \\
2 \\
2 \\
2 \\
2 \\
2 \\
2 \\
2 \\
2 \\
2\end{array}$ & $\begin{array}{r}6.7500 \\
5.7267 \\
2.5586 \\
.1093 \\
.2977 \\
.2386 \\
2.0927 \\
5.9661 \\
1.7660 \\
6.6483 \\
.0544\end{array}$ & $\begin{array}{l}1 \\
1 \\
1 \\
1 \\
1 \\
1 \\
1 \\
1 \\
1 \\
1 \\
1 \\
1 \\
1\end{array}$ & $\begin{array}{l}.0094 \\
.0167 \\
.1097 \\
.7409 \\
.5853 \\
.6252 \\
.1480 \\
.0146 \\
.1839 \\
.0099 \\
.8155\end{array}$ & $\begin{array}{r}7.4810 \\
5.9273 \\
2.6361 \\
.1111 \\
.3049 \\
.2418 \\
2.0946 \\
5.8727 \\
1.8098 \\
7.0932 \\
.0547\end{array}$ & $\begin{array}{l}2.50 \\
2.19 \\
1.28 \\
-.63 \\
-.22 \\
-.33 \\
1.06 \\
2.18 \\
.94 \\
2.43 \\
-.84\end{array}$ & $\begin{array}{r}1 \\
2 \\
3 \\
4 \\
5 \\
6 \\
7 \\
8 \\
9 \\
10 \\
11\end{array}$ & $\begin{array}{l}\text { I0001 } \\
\text { I0002 } \\
\text { I0003 } \\
\text { I0004 } \\
\text { I0005 } \\
\text { I0006 } \\
\text { I0007 } \\
\text { I0008 } \\
\text { I0009 } \\
\text { I0010 } \\
\text { I0011 }\end{array}$ \\
\hline
\end{tabular}

Gambar 9 Faktor Bias Masa Kerja

Item yang bias dengan masa kerja adalah item saya sangat bersungguh-sungguh sebagai dosen, pekerjaan sebagai dosen menyita waktu, saya memiliki ikatan emosional dengan perguruan tinggi, dan saya memiliki kewajiban untuk tetap berada pada perguruan tinggi ini. 
Employee engagement merupakan ukuran atau variabel yang telah banyak digunakan dalam berbagai penelitian di bidang ilmu perilaku organisasi, namun engagement yang khusus mengukur tenaga pengajar pendidikan tinggi, atau engagement dosen merupakan suatu ukuran yang belum banyak digunakan. Penelitian ini merupakan tahap pertama atau pilot study untuk mencari ukuran yang tepat dalam mengukur engagement dosen, khususnya pada perguruan tinggi di Indonesia, dan negara lain dengan karakteristik yang sama.

Penelitian ini menggunakan 13 ukuran atau item yang awalnya digunakan untuk mengukur employee engagement (Sak, 2006). Pada tahap pertama untuk mendapatkan ukuran yang terkait engagement dosen, nilai Cronbach Alpha yang kurang baik, person reliability yang rendah namun item reliability yang sangat baik menunjukkan bahwa konsistensi jawaban dari 136 responden lemah, namun kualitas item instrumen bagus. Ketidakkonsistenan jawaban responden ini bisa jadi karena sebagai besar responden adalah dosen yang memiliki masa kerja sebagai dosen tetap masih rendah, dibawah 6 tahun. Dari hasil nilai separation juga menunjukkan bahwa responden terdiri dari dua kelompok, yang artinya responden cenderung tidak homogen.

Hasil analisa pada item ukuran engagement dosen, terlihat bahwa untuk item no. 2, yaitu "menjadi dosen menyita sebagian waktu saya" merupakan item yang sukar untuk disetujui oleh responden, karena sebagian besar responden atau dosen tidak bekerja secara penuh waktu dan kerancuan jawaban, karena dosen identik dengan mengajar, sehingga responden tampaknya tidak mempertimbangkan hal lain seperti penelitian dan pengabdian kepada masyarakat sebagai kegiatan dosen. Sebaliknya, item no. 1, yaitu "Saya bersungguh-sunguh menjalani profesi saya sebagai dosen"adalah item yang sangat mudah disetujui oleh responden, sebagian besar responden menjawab sangat setuju untuk item ini, dan merasa memang bekerja dengan sungguh-sungguh dalam menjalani profesinya sebagai dosen.

Selanjutnya, item pengukuran dipastikan apakah memang merupakan item yang cocok dengan person. Dengan 3 pengujian, terlihat bahwa item no. 11 "Sulit untuk meninggalkan perguruan tinggi ini, meskipun keinginan ada" merupakan item yang membingungkan dan sulit dijawab oleh responden. Hal ini bisa jadi karena pertanyaan tersebut sebenarnya adalah double barel question, dan juga favorabel namun unfavorable question di satu sisi, yaitu mengukur dua hal yang berbeda. Pertama adalah mengukur sulit meninggalkan perguruan tinggi ini, dan yang kedua adalah mengukur keinginan untuk meninggalkan perguruan tinggi.

Item yang juga sulit dijawab oleh responden dan juga membingungkan bagi responden adalah item no.8 "permasalahan perguruan tinggi ini adalah juga permasalahan saya" item ini membingungkan bagi responden. Hal ini bisa jadi karena sebagai tenaga pendidik atau dosen, adalah lebih ke arah profesional atau profesi pribadi. Dimana pada profesional, ukuran organisasi biasanya bukan menjadi hal yang dijadikan prioritas utama.

Namun, walaupun terdapat dua item yang sepertinya misfit atau membingungkan bagi respnden, ternyata ke 13 item ini mengukur apa yang hendak diukur, yaitu mengukur tingkat engagement dosen. Artinya apabila ada penelitian yang ingin mengukur tingkat engagement dosen, maka ke 13 item ini telah membentuk 1 faktor atau 1 dimensi.

Terakhir pengujian instrumen ini menyarankan untuk tetap menggunakan empat skala likert rating scale, 1 untuk sangat tidak setuju, 2 untuk tidak setuju, 4 untuk setuju, dan 5 untuk sangat setuju. Skala genap dengan menghilangkan netral atau cukup di tengah cocok untuk mengukur organisasi, sehingga dapat dilihat kecenderungan responden dalam menjawab. Apablia menggunakan skala ganjil, maka responden yang tidak berani untuk tidak setuju akan cenderung menjawab netral. 


\section{SIMPULAN DAN SARAN}

Terdapat beberapa kesimpulan yang bisa ditarik dari hasil penelitian ini. Pertama, untuk mengukur komitmen dan keterikatan dosen pada perguruan tinggi swasta di Indonesia terdapat 11 item dari 13 item yang bisa digunakan, yaitu 13 ukuran, yang diambil dari beberapa sumber pada kajian literatur, yaitu: bersungguh-sungguh menjalani profesi; profesi yang menyita waktu; keterlibatan dengan profesi dosen,; merasa berarti sebagai dosen; kebanggaan sebagai dosen; keterlibatan dengan organisasi; menghabiskan karir pada organisasi; ikatan emosional pada organisasi; kebutuhan untuk bertahan pada organisasi; kerugian meninggalkan organisasi; dan perasaan bersalah meninggalkan organisasi.

Kedua, untuk mengukur komitmen dosen pada perguruan tinggi swasta, dapat menggunakan empat pengukuran skala likert, mulai dari sangat tidak setuju sampai sangat setuju. Ketiga apabila ingin mengukur komitmen dosen pada pergruan tinggi, ke- 11 pengukuran di atas tidak bias terhadap jenis kelamin dan masa kerja, artinya ke 11 pengukuran komitmen dosen ini memberikan kecenderungan jawaban yang sama baik dari dosen pria maupun wanita. Dan juga memberikan kecenderungan jawaban yang sama bagi dosen dengan masa kerja lama dan masa kerja baru.

\section{DAFTAR RUJUKAN}

Agyemang, C. B,. \& Ofei, S. B. (2013). Employee Work Engagement and Organizational Commitment : A Comparative Study of Private and Public Sector Organizations In Ghana. European Journal of Business and Innovation Reasearch, Vol.1 No.4, pp.20-33.

Albdour, A.A. \& Altarawneh, I.I. (2014). Employee Engagement and Organizational Commitment: Evidence From Jordan. International of Business, Vol.19, No 2.

Allen, N.J., Meyer, J. P. \& Smith, C.A. (1993). Commitment Organizational and Occupations: Extension and Tes of Three Component Conceptualization. Journal of Applied Psychology. 78, 538-551.

Allen \& Meyer, J.P. (1991). The Measurement and Antecedents of Affective, Continuance and Normative Commitment to the Organizational. Journal of Occupational Psychology, 63 (1): 1- 18.

Anindita \& Seda. (2018). How Employee Engagement Mediats the Influences of Individual Factors toward Organizational Commitment. Problems and Perspective in Management. Vol. 16. No. 1.

Azwar, S. (2012). Penyusunan Skala Psikologi. Edisi II. Yogyakarta: Pustaka Pelajar.

Bakker, A.B. \& Leiter, M.P. (Eds). (2010). Work Engagement: A handbook of essential theory and research. New York, NY: Psychology Press.

Gallup Organization (2005). Employee Engagement: The Engagement side of the Human Sigma Equation. Retrived from www.gallup.com.

Khalid, A. \& Khalid, S. (2015). Relationship Between Organizational Commitments, Employee Engagement, and Career Satisfaction A Case Of University of Gujrat, Pakistan. J. S. Asian Stud. 03 (03) 2015. In Press.

Hair., Anderson., Tatham. \& Black. (2008). Multivariate. Data Analysis Fifth Edition USA. Prentice Hall International Inc.

Harter, J.K., Schmidt, F.L. \& Hayes, T.L. (2002). Business-unit-level Relationship Between Employee Satisfaction, Employee Engagement, and Business Outcomes: A Meta-Analysis. Journal of Applied Psychology: 87: 258279.

Jaros, S. (2007). Meyer and Allen Model of Organizational Commitment: Measurement Issues. The Icfai Journal of Organizational Behavior, Vol. VI, No. 4.

Markos, S. \& Sridevi, M.S. (2010). Employee Engagement : The Key to improving Performance. International Journal of Business and Management, Vol. 5, No. 12.

Metha, D., \& Metha, N.K. (2013). Employee Engagement: A Literature Review. Economica. Seri Management, Vol. 16, No.2.

Meyer, J.P. \& Allen, N. (1997). Commitment in the Workplace: Toward a General Model. Human Resource Management Review, Vol. 11, pp. 299-326.

Meyer \& Herscovitch, L. (2001). Commitment in the Workplace: Toward a General Model. Human Resource Management Review, Vol. 11, pp. 299-326.

Mowday, R.T., Steers, R.M. \& Porter, L.W. (1979).The Measurement of Organizational Commitment. Journal of 
Vocational Behavior, 14, pp. 224-247.

Noe, R.A. (2000). Toward an Integrative Theory of Training Motivation: A Meta-Analytic Path Analysis of 20 Years of Research. Journal of Applied Psychology, Vol. 85, No. 5, 678-707.

Ologbo, A.C., \& Sofian, S. (2012). Individual Factors and Work Outcomes of Employee Engagement. Procedia Social and Behavioral Sciences, Vol. 40, 498 - 508.

Ologbo, A.C. \& Sofian, S. (2013). Individual and Organizational Factors of Employee Engagement on Employee Work Outcomes. International Journal of Business and Behavioral Sciences, Vol.3, No. 3.

Ortiz, D.C. \& Lau, W.K. (2011). The Effect of Employee Engagement on Continuance and Normative Commitment to The Organization. Marshall University, Marshal Digital Scholar Management Faculty Research Management, Marketing, and MIS.

Perrin, T. (2003). Working Today: Understanding What Drives Employee Engagement. The 2003 Towers Perrin Talent Report U.S Report [Online] Availablel: http:/www.towersperrin.com/tp/getwebcachedoc.

Robinson, D., Perryman, S. \& Hayday, S. (2004). The Drivers of Employee Engagement. Report 408, Institute for Employement Studies, UK.

Saks, A.M. (2006). Antecendents and Consequences of Employee Engagement. Journal of Managerial Psychology: 21 (6): 600-619.

Shoko and Zinyemba. (2014). Impact of Empoyee Engegement $\mathrm{n}$ Organizational Commitment in National Instituion of Higher Learning in Zimbabwe. Inernational Journal of Advanced Research in Management and Social Sciences. Vol.3 No. 9

Zulkarnain dan Hadyani,(2014). Peranan Komitmen dan EMploeen ENggement terhadap Kesiapan Karyawan untuk Berubah. Jurnal Psikologi UGM. VO1. 06. No. 05 